\title{
ARGUMENTASI FILISOFIS AL-KINDI, IBN RUSYD, DAN AL- FARABI TENTANG KEKEKALAN ALAM
}

\author{
Mulyadi*
}

\begin{abstract}
ABSTRAK
Artikel ini ingin membahas tentang pedebatan empat filsuf Islam terkemuka mengenai qadimnya alam yang sampai hari ini masih terus menjadi topik yang terus menjadi perbincangan hangat oleh kalangan pengkaji filsafat dan para teolog. Dalam filsafat Islam hal ini tidaklah merupakan hal yang aneh untuk diperbincangkan. Para failasuf seperti al-Kindi, Ibn Rusyd, al-Farabi, dan al-Ghazali memiliki argumentasi tersendiri terhadap permasalahan qadim dan barunya alam. Seperti Ibnu Rusyd misalnya, dengan berbagai argimentasi yang terpengaruh oleh Aristoteles mengakatan bahwa alam ini qadim. Hal ini mendapat sanggahan keras dari al-Gazali yang ia tuangkan dalam bukunya Thahafuz al-Falasifah. Namun seperti yang kita ketahui bahwa al-Ghazali mengungkapkan kerancuan para failasuf ketika ia telah menjadi seorang sufi. Demikian pula dengan al-Kindi dan al-Farabi, mereka tetap bertahan dengan pendapatnya yang begitu kontroversial. Menganai hal qadim dan baharunya alam kita akan sedikit melihat beberapa argumen dari al-Kindi, Ibnu Rusyd, dan al-Farabi.
\end{abstract}

\section{Kata Kunci: Al-Kindi, Ibn Rusyd, Al-Farabi, Filsafat, Qadim, Alam}

\section{PENDAHULUAN}

Perdebatan mengenai kekekalan alam dan proses kemaujudannya selalu menjadi perbincangan hangat dikalangan para filsuf dari masa ke masa. Tidak hanya dikalangan para failasuf maupun dikalangan para pengkaji filsafat, pengetahun mengenai alam masih menjadi misteri mengenai kelanjutan pasca kehancurannya. Failasuf Muslim memiliki interpretasi sendiri dalam menjelaskan bagaimana pengetahuan tentang kadim dan barunya alam dengan menggunakan akal dan ada pula yang menyatukan antara Firman Allah Swt, dengan pengetahuan akal.

* Penulis adalah Dosen Institut Agama Islam Negeri Langsa, Email yadimulia85@yahoo.co.id 
Pendapat-pendapat tersebut bukan sekedar sebuah persepsi cacat semata, melainkan diperoleh atas dasar kontemplasi imajinasi dan kontemplasi intelektual. Kehancuran alam kelak bukan semata menamatkan alam ini yang merupakan bagian dari diri manusia, melainkan babak baru untuk kehidupan selanjutnya dalam memulai perjalan kehidupan setelah kematian. Kefanaan alam ini hanyalah bentuk lain dari salah satu janji Allah Swt, kepada manusia dalam firman-Nya. Alam ini berasar dari tiada kemudian menjadi ada bagaimana proses kemaujudannya menurut akal dan interpretasi kewahyuan. Demikian pula dengan beberapa pandangan yang akan dilihat yaitu bahwa alam ini akan hancur akan tetapi materinya akan kekal, sebab materi maujud bersamaan dengan adanya Allah Swt.

\section{AL-KINDI}

Al-Kindi berpendapat bahwa di dalam benda yang memiliki fisik memiliki unsur materi dan membutuhkan ruang dan waktu untuk bergerak. Materi, bentuk, ruang, waktu, merupakan unsur yang mesti ada disetiap fisik. Wujud, yang begitu erat kaitannya dengan fisik, ruang dan waktu, adalah terbatas, karena kombinasi itu takkan ada, kecuali dalam keterbatasan. Dalam pandangan al-Kindi, waktu bukanlah gerak, melainkan hanyalah sebagai bilangan pengukur gerak, sebab menurutnya waktu tidak lain hanyalah yang terdahulu dan yang akan datang (dahulu dan yang kemudian). Waktu tidaklah dapat kita sebutkan sebagai bilangan yang tunggal melainkan bilangan yang berkesinambungan, oleh sebab itu waktu dapat ditentukan yang berproses dari dahulu hingga nanti. Dengan sintem seperti ini maka waktu merupakan jumlah yang dahulu dan yang berikut dan waktu adalah berkesinambungan (M. M. Syarif, 1992: 24). Sedangkan gerak tidak lain hanyalah gerak massa, maka jika massa itu ada maka gerak akan ada pula dan sebaliknya. Sedangkan perubahan mengenai esensi massa merupakan suatu pengadaan atau peniadaan. Setiap perubahan merupakan penghitungan periode terhadap suatu massa yang mengalami perubahan tersebut. Maka setiap bentuk perubahan itulah yang sebenarnya disebut dengan waktu. Perubahan itu sendiri ialah ketersusunan dan keterhimpunan, karena perubahan ini membentuk suatu pengaturan dari berbagai sesuatu serta menggabungkannya. Massa sebenarnya esensi yang berdimensi tiga yaitu panjang, lebar, dan tinggi, dan terdiri dari materi dan bentuk. Sedangkan ketersusunan sebarnya lazim kita dengar yaitu sesuatu perubahan dari sesuatu yang semula tidak tersusun, maka ketersusunan adalah gerak, jika tidak ada gerak maka tidak ada pula ketersusunan. Massa adalah tersusun, jika tidak ada gerak maka tidak ada massa, maka massa dan gerak berjalan dengan beriringan. Maka adanya gerak itu ada pula waktu tersebut, karena gerak merupakan 
perubahan dan perubahan merupakan suatu penghitung periode bagi yang mengalami perubahan itu. Maka waktu ialah periode yang terhitungkan oleh gerak (Nurcholish Madjid, 1994: 87-94).

Maka jelaslah bahwa tidak mungkin suatu massa tidak terhingga. Segala apapun yang terhingga dengan sendirinya adalah terhingga pula. Setiap apapun yang termuat dalam massa seperti kuantitas, atau tempat, waktu, gerak, serta keseluruhan apasaja yang terdapat di dalam massa adalah terhingga pula, karena massa terhingga. Jadi massa keseluruhan alam adalah terhingga, dan segaga apapun yang berada di dalamnya dan seterusnya adalah terhingga pula. Jadi alam ini secara potensial saja tidak terhingga, sebab potensi tidak lain hanyalah kemungkinan, sedangkan secara aktual tidak mungkin ada sesuatu yang tak terhingga. Kemudian alKindi memberikan penjelasan terhadap apa yang disebut kualitas dan kuantitas. Baginya kualitas adalah kapasitas untuk menjadi sama dan tidak sama; sedangkan kuantitas adalah kapasitas untuk menjadi sejajar dan tidak sejajar. Bagi al-Kindibahwa ruang, gerak, dan waktu merupakan kuantitas.

Pertanyaan al-Kindi selanjutnya ialah apakah mungkin sesuatu menjadi sebab bagi wujud dirinya, ataukah itu tidak mungkin terjadi. AlKindi menjawab bahwa itu tidaklah mungkin terjadi. Alasannya ialah, alam ini adalah baru dan ada permulaan waktunya, karena alam ini terbatas. Oleh karena ada keterbatasan alam, maka mesti ada yang menyebabkan ini terjadi. Alam menempati keberadaan kita merupakan sesuatu yang baru dan ada permulaan waktunya, karena alam ini terbatas. Oleh karena keterbatasannya, maka mestilah ada yang menyebabkan alam ini terjadi, tidak mungkin ada benda yang ada dengan sendirinya, maka ia diciptakan dari ketiadaan. Argumentasi mengenai hukum sebab, alam itu bukan penyebab bagi dirinya sendiri, karena kalau alam itu menjadi sebab bagi dirinya sendiri maka tidak ada habis-habisnya dan sesuatu yang berakhir tidak mungkin terjadi. Oleh karena itu maka sebab mestilah adanya di luar yang disebabkan dan pastinya lebih mulia, lebih tinggi serta lebih dahulu adanya (Ahmad Hanafi, 1990: 77).

Al-Kindi tidak sependapat dengan Aristoteles yang mengatakan bahwa alam itu qadim adanya. Dengan membagun konsep metafisik, Arsitoteles memberikan pembuktian tentang Penggerak Pertama, namun al-Kindi lebih mengedepankan doktrin al-Qur'an tentang penciptaan dari ketiadaan (ex nibilo). Arguman yang dimunculkan oleh al-Kindi merupakan sebuah argumen yang pregresif bagi Tuhan (Karen Amstrong, 2012: 275). Tuhan merupakan sebab utama (First Cause) dimana adanya Ia tidak disebabkan oleh sebab yang lain. Al-Kindi dengan tegas mengatakan bahwa sebenarnya Tuhan merupakan Pencipta bukan Penggerak Pertama sebagaimana pendapat Aristoteles. Karena jika Penggerak berarti telah ada 
sesuatu sebelumnya yang kemudian disatukan menjadi bentuk dari sesuatu unsur. Dalam hal ini al-Kindi kelihatan lebih dekat dengan filsafat Plotinus (A. Hanafi, 1983: 56-68) yang mengatakan bahwa Yang Maha Satu adalah asas dari segala yang ada. Bagi al-Kindi, Allah Swt adalah Zat yang menciptakan, tetapi bukan diciptakan, Ia menciptakan sesuatu yang semula dari tiada. Ia adalah Zat yang Maha menyempurnakan namun bukan disempurnakan.

\section{IBNU RUSYD}

Kita akan memulai argumentasi Ibnu Rusyd tetang qadimnya alam Mengenai konsep gerak. Dalam pandangan Ibn Rusyd, alam semesta ini bergerak dengan gerak yang abadi, namun untuk keabadian tersebut gerak ini membutuhkan Penggerak Pertama yang bergerak bukan dengan benda dan bukan dengan sesuatu apapun yaitu Tuhan. Berbeda dengan Aristoteles, Ibnu Rusyd mengatakan bahwa gerak benda-benda langit itu dijadikan oleh Penggerak Pertama dari ketiadaan kemudian menjadi ada namun bukan dalam zaman, karena zaman tidak mungkin mendahului wujud perkara yang bergerak, selama zaman itu kita anggap sebagai ukuran geraknya. Jadi gerakan menghendaki adanya Penggerak pertama atau sesuatu sebab yang mengeluarkan dari tiada menjadi ada (Ahmad Hanafi, 1990: 172).

Terhadap teori kausalitas, Ibnu Rusyd memberikan pendapat bahwa terhadap sesuatu apapun, apakah itu kejadian baru, penciptaan, memerlukan form baru, dan pada setiap form mestilah ada obyeknya atau dengan kata lain bendanya yang ditempati. Dengan kata lain dari perkara baru yang ditimbulkan mestilah ada perkara baru pula yang harus dimunculkan. Berarti penciptaan atau perbuatan ini tercipta dengan adanya Zat-pembuat yang mengadakan semua substansi baru. Perbuatan ini ialah dengan cara menggerakkan benda atau dengan mengingat benda tersebut kepada-Nya. Untuk itu Ibnu Rusyd memberikan pengertian terhadap penciptaan yang sebabnya penciptaan tersebut tidaklah langsung dan bukan pula dari tiada kemudian ada, melainkan melalui apa yang disebutnya sebagai bule (bahan) lama, yang kemudian digerakkan dari sekdar wujud potensi (kemampuan) menjadi wujud yang nyata, maka terjadilah substansi yang berganti-ganti itu, baik bendanya itu sendiri maupun form-formnya.

Dalam pandangan Ibnu Rusyd substansi (wujud) yang lebih awal itulah yang memberikan wujud kepada substansi yang kemudian tanpa memerlukan kepada Pemberi form yang berada di luarnya. Dengan bahasa yang lebih sederhana bahwa setiap wujud (perkara) menimbukan sejenisnya dengan tidak membutuhkan kepada Zat-pembuat yang terpisah 
daripadanya, sebab suatu benda yang berisikan Form pada sesuatu perkara, dengan melalui kekuatan-kekuatan positifnya bisa mengubah perkara tersebut kepada keadaan yang harus dimilikinya untuk menerima form yang baru, dan dapat mengadakan form pada benda yang telah berubah itu. Jadi terjadinya wujud-wujud mengikuti adanya kemusnahan apa yang ada sebelumnya dengan hukum yang tetap dan yang tidak meleset. Ibnu Rusyd memberikan ketetapan bahwa tiap-tiap sesuatu mempunyai sebab yang mempengaruhi kepada apa yang datang sesudahnya dan terpengaruh oleh apa yang ada sebelumnya dan seterusnya hingga sampai kepada Sebab yang Pertama (Ahmad Hanafi, 1990: 174).

Menurut pendapat Ibn Rusyd, ada dua perkara yang azali yaitu Tuhan dan alam. Akan tetapi ini berlainan satu sama lain, azalinya Tuhan berbeda dengan azalinya alam, karena Tuhan merupakan wujud dari alam tersebut. Untuk memperkuat argumentasinya mengenai kekadiman alam, Ibn Rusyd menggunakan ayat-ayat al-Quran untuk mendukungnya. Seperti yang di kutip oleh Ahmad Hanafi dalam buku Faslul-Maqal yang ditulis oleh Ibnu Rusyd;

"Karena menurut lahirnya Syara', apabila diteliti maka akan tampak dari ayat-ayat yang mengenai kabar tentang terjadinya alam bahwa form-nya baru benar-benar, dan bahwa wujud dan zaman itu sendiri berlangsung terus dari kedua ujungnya, yakni tidak terputus, sebeb firman Allah: Tuban adalab Zat yang membuat langit dan bumi dalam enam hari, dan arasy-Nya di atas air (QS Hud/11:7), menurut lahirnya menunjukkan adanya wujud sebelum wujud ini, yaitu 'arasy dan air, dan adanya zaman yang menyertai gambaran wujud yang berupa bilangan benda-benda angkasa."

Disisi lain mengenai hari akhirat Allah berfirman; "Hari bumi diganti bukan dengan bumi, dan langit pula..”. (QS Ibrahim/14:48). Dari penggalan ayat ini menunjukan adanya wujud lain kemudian setelah wujud yang ada ini. Kemudia Ibnu Rusyd membuktikan adanya dukungan ayat lain; "Kemudian Ia menuju ke langit dan itu masih berupa asap..". (QS Fussilat/41:11), "langit dan bumi keduanya dulu menyatu, kemudian Kami pisabkan antara keduanya..." (QS al-Ambiya'/ 21:30). Dari keterangan beberapa ayat tersebut, Ibnu Rusyd berpendapat bahwa penciptaan alam dari tiada kemudian ada itu masih perlua diragukan. Pasalnya adalah untuk menciptakan langit, Allah tidak lebih dari hanya sekedar menggerakkan secara tidak langsung terhadap kabut yang bercampur aduk. Dengan kata lain form langit yang ada saat ini adalah perpindahan dari yang semula bersifat potensi kemudian diaktualkan menjadi bentuk yang nyata. Selanjutnya adalah kejadian serta kehancuran alam ini disebabkan oleh gerak, perkara pergerakan tersebut adalah bule atau materi yang belum 
terbentuk yang kemudian menerima bermacam-macam form. Singkatnya ialah bahwa bule itu adalah sesuatu kemungkinan murni yang tidak menerima kemusnahan atau kejadian. Kelanjutan dari ini adalah bahwa gerak yang terus-menerus itu tidak berkesudahan dalam menjadikan apa yang bersifat potensi menjadi wujud yang nyata.

Dengan berbagai arguman di atas, Ibnu Rusyd mengakatakan alam itu kadim, namun disisi lain ia juga meencoba memberi pemahaman bahwa alam itu baru. Ini seperti argumen yang bertolak belakang satu dengan yang lain. Dalam Faslul-Maqal karya Ibnu Rusyd, Hanafi mengutipnya sebagai berikut:

"Wujud yang pertama adalah wujud dari sesuatu yang lain karena sesuatu, yakni karena Zat-pembuat dan dari benda, sedangkan zaman pun mendabuluinya. Ini adalah kedaan benda-benda dimana kejadiannya bisa terlibat oleh indera, seperti terjadinya air, udara, bumi, hewan, tumbuban, dan sebagainya. Wujud tersebut disepakati namanya oleh para filosof dan golongan Asy'ariyah sebagai wujud baru. Wujud yang berlawanan dengan itu ialah Wujud yang bukan dari sesuatu, tidak. karena sesuatu, dan tidak. didabului oleh zaman. Wujud inipun disepakati namnya oleh kedua golongan tersebut sebagai Wujud-qadim. Wujud serupa ini dapat diketahui dengan bukti-bukti pikiran, yaitu Allah SWT, yang memperbuat dan ciptakan segala sesuatu serta memeliharanya. Adapun wujud yang terletak diantara kedua wujud tersebut di atas, tetapi wujud karena sesuatu, yaitu Zat-pembuat, dan wujud tersebut adalab alam keselurubannya. Semua golongan sepakat pendapatnya tentang adanya ketiga sifat (keadaan) tersebut bagi alam, yaitu bukan dari tiada, tidak didabului zaman dan terjadi karena Zat-pembuat. Ulama-ulama kalam mengakui bahwa zaman tidak. mendabului alam, atau sebenarnya mengakui demikian, karena bagai mereka zaman adalah sesuatu yang menyertai gerakan dari benda. Wujud yang tengah-tengah tersebut kedudukannya sudah jelas karena ada kemiripannya dengan Wujud-qadim, dan ada kemirupan dengan wujudbaru. Bagi mereka yang menguatkan segi kemiripannya dengan wujud yang qadim, maka mereka menamakanya Wujud-qadim. Sebaliknya mereka yang lebih menguatkan segi kemiripannya dengan wujud-baru maka mereka menamakannya wujud baru. Sebenarnya alam semesta ini bukan wujud baru, bukan pula wujud-qadim yang sebenarmya, sedangkan wujud-qadim yang sebebnarnya mestilah musnah, sedangkan wujud-qadim yang sebenarnya tidak mempunyai (illat) sebab bagi wujudnya. Oleh karena itu ada sementara orang yang menamakan wujud ketiga, yaitu wujud alam semesta, sebagai wujud baru-azali, karena zaman itu berkesudahan pada masa lampau. Mereka adalab Plato dan pengikut-pengikutnya". 
Baginilah pendapat Ibnu Rusyd mengenai kekadiman dan kebaharuannya alam. Perlu digaris bawahai bahwa Ibnu Rusyd mengakui bahwa Tuhan yang membuat alam tersebut sehingga menjadi ada. Namun penciptaan tersebut bukan dari tiada melainkan dari yang telah ada sebelumnya, mungkin yang yang ia maksut materi tersebut adalah materi asal alam ini. Materi asal alam ini tidak didahului dengan waktu, melainkan adanya materi awal yang berubah menjadi ada dalam bentuk lain. Kemudian yang menjadi persoalan baginya adalah mendahuluinya zaman atas alam, ataukah zaman dan alam itu wujud bersama-sama. Ibnu Rusyd mengatakan bahwa alam ini qadim, karena berwujudnya alam atas kemauan Tuhan, sedangkan kemauan Tuhan tidakk bisa ditolak dengan tidak memiliki permulaan. Sedangkan zat-pembuat tersebut kadangkadang bekerja dan terkadang tidak bekerja, maka oleh sebab itu haruslah ada penyebab Utama yang mesti menggerakkannya untuk menjadikan sesuatu menjadi ada. Jadi asusmsinya mungkin demikian, bahwa zatpembuat itu adalah sesuatu yang memunculkan bentuk tertentu yang masih bersifat potensial. Namun atas gerakan yang dimunculkan oleh Penggerak Pertama maka zat-pembuat ini aktif sehingga memunculkan sesuatu wujud yang kemudian teraktualkan. Demiakian seterusnya hingga terbentuknya alam ini.

\section{AL-FARABI}

Argumen al-Farabi mengenai penciptaan alam dan juga kekadiman alam bermuara pada konsep emansi. Segala sesuatu yang ada saat ini adalah apa yang telah keluar dari Tuhan, karena Tuhan mengetahui zatNya dan kemudian Ia menjadi dasar atas segala wujud yang ada. Dalam proses penciptaan alam ini, Tuhan hanya cukup mengetahu zat-Nya maka alam ini terwujud. Berbeda dengan Ibnu Rusy, al-Farabi berpendapat bahwa keluarnya alam dari Tuhan tanpa gerak, alat atau materi, karena pekerjaan emanasi adalah pekerjaan akal semata. Dalam filsafatnya ini alFarabi sebagaimana halnya Plotinus menerangkan bahwa segala yang ada atau alam ini memancar dari Zat Tuhan melalui akal-akal yang berjumlah sepuluh. Antara alam materi dengan Zat Tuhan terdapat pengantara. Tuhan berpikir tentang diriNya, dan dari pemikiran ini memancarlah Akal Pertama. Akal Pertama berpikir tentang Tuhan, dan dari pemikiran ini memancarlah Akal Kedua. Akal Kedua berpikir tentang Tuhan, dan dari pemikiran ini memancarlah Akal Ketiga. Demikian seterusnya sampai memancar Akal Kesepuluh. Akal Pertama selanjutnya berpikir tentang dirinya, dan dari pemikiran ini timbullah langit pertama. Akal-akal lainnya juga berpikir tentang dirinya masing-masing, dan dari pemikiran itu timbullah planet-planet yang menghuni alam ini. Dengan demikian Tuhan 
Yang Maha Esa tidak mempunyai hubungan langsung dengan alam materi yang mengandung arti banyak ini. Demikian penjelasan Al-Farabi mengenai bagaimana yang banyak bisa muncul dari Yang Satu (Tuhan) $(H$. A. Mustofa, 1997: 160-162).

Dalam persoalan masalah qadimnya alam, al-Farabi mengikuti Aristoteles. Dalam pandangan Aristoteles bentuk merupakan hakikat sesuatu sehingga ia kekal dan tidak memiliki perubahan. Akan tetapi dalam panca indra yang terdapat perubahan dan perubahan tersebut menghendaki perubahan itu terjadi, dasar inilah yang mungkin disebut materi oleh Aristoteles. Baginya pula bentuk yang kekal namun materilah yang berubah-ubah. Bentuklah yang membuat materi berubah, materi tersebut berubah untuk menemukan bentuk tertentu. Dengan memperoleh bentuk tersebut, materi mempunyai pontesi dan kemudian dapat teraktualkan. Diantara bentuk dan materi terdapat hubungan gerak, sedangkan untuk mengaktualkanya mesti ada Penggerak Pertama. Keseluruhannya materi membutuhkan Penggerak Utama untuk menjadi sesuatu.Namun mengingat dia adalah seorang Muslim maka ia mencoba mempertemukan pendapat Aristoteles dengan ketentuan agama Islam mengenai Khalq (pencipta). Ia meyakini bahwa alam ini diciptakan Tuhan, namun dalam pandangan al-Farabi benda langit diciptakan oleh Tuhan dengan tidak mengikuti dengan waktu. Dengan kata lain bahwa alam tercipta di luar segala sesuatu yang tianda didahului oleh waktu (Oliver Leaman, 1988: 45). Sebagai seorang muslim, ia mencoba mensucikan Tuhan dari materi dengan mengalihkan kepada teori akal.Dengan kata lain Tuhan cukup melukiskan untuk mengadakan sesuatu yang ingin di wujutkan-Nya.Jadi pemikiran Tuhan terhadap alam tidaklah langsung, melainkan cukup melalui Zat-Nya, kemudian kedudukan-Nya sebagai sebab adanya alam semesta beserta peristiwanya.

Terpengaruh oleh Aristoteles,al-Farabi mencoba menjelaskan bagaimana terbentuknya materi melalui proses emanasi Tuhan. Materimateri utama atau yang al-Farabi sebutkan dengan kata byle dilahirkan oleh inteligesi kesepuluh. Hyle ini terdiri atas empat unsur yaitu air, api, tahan, dan udara, dari intelegensi itu pula muncullah bentuk-bentuk yang berlainan yang menyatu dengan byle tersebut guna membentuk sebuah wadah. Alam ini merupakan serangkaian bentuk materi yang berbeda-beda kemudian menyatu satu dengan lainnya. Pertumbuhan merupakan hasil persatuan bentuk dan materi, sedangkan kerusakan merupakan hasil pemisahan mereka. Semua intelegensi yang terpisah menghasilkan gerak yang bermanfaat bagi alam semesta (Syarif, 1992: 68). Semua materimateri tersebut membutuhkan Penggerak Pertama untuk dijadikan bentuk tubuh langit pertama dan seterusnya. Sebagai proses apa yang disebut 
wujud potensial berkembang melalui bentuk menjadi wujud aktual, secara tidak langsung adalah yang menggabungkan materi dan bentuk baru. Teori emansi Ibnu Rusyd, yaitu akal pertama sampai akal kesepuluh yang biasa disebut dengan 'aql al fa'al meruapakan aktifitas pengaktualan di dunia sebagai penghasil materi dan pemberi bentuk setiap materi serta jiwa bagi setiap benda ketika benda tersebut siap menerimnya. 'Aql al fa'al juga merupakan sumber keberadaan jiwa manusia. dengan kata lain, al-Farabi mengatakan bahwa alam diciptakan Tuhan bukan dari ketiadaan pada saat masa yang telah berlalu melainkan dari sesuatu yang telah ada. Dengan konsekuensi ini dapat membawa kita berkesimpulan bahwa alam ini qadim, yakni tidak bermula dalam waktu, bersifat kekal dan tidak hancur (Majid Fakhry, 1987: 183).

\section{Kesimpulan}

Sesuai dengan paham yang ada dalam Islam, Tuhan bagi al-Kindi adalah sebagai pencipta bukan sebagai penggerak. Alam ini memiliki permulaan bukan dari zaman yang telah berlalu, maka oleh sebab itu alam ini terbatas dan tidaklah azali sebagaimana azalinya Tuhan. Namun Ibnu Rusyd memiliki pandangan lain bahwa alam ini kekal karena materinya telah ada sebelumnya, namun materi tersebut membutuhkan Penggerak Pertama untuk pengaktualannya. Wujudnya alam ini atas kemauan Tuhan, jadi ia akan kekal bersama Tuhan. Mungkin yang dimaksut oleh Ibnu Rusyd apa yang kekal bersama Tuhan adalah materi asal mula alam ini yang tidak didahului oleh waktu. Kalau kita lihat Ibnu Rusyd berdasarkan pemikirannya ia tergolong ke dalam rasionalisme, namun disisi lain ia mengakui adanya realitas yang tidak dapat dirasionalkan yang hanya mungkin bisa dipahami oleh kerangka agaman dan iman. Dengan bahasa yang lebih sederhana, Ibnu Rusyd merupakan failasuf yang sangat rasional namun disisi lain sangat agamis. Selaras dengan Ibnu Rusyd, al-Farabi juga mengatakan alam ini kekal karena penciptaannya tidak didahului oleh waktu. Sekilas ini sama dengan pendapat Ibnu Rusyd, namun al-Farabi mengatakan bahwa materi itu muncul dari proses emanasi. Teori emansi yang merupakan akal pertama sampai akal kesepuluh disebut oleh alFarabi sebagai 'aql al fa'alyang meruapakan aktifitas pengaktualan di dunia sebagai penghasil materi dan pemberi bentuk setiap materi serta jiwa bagi setiap benda ketika benda tersebut siap menerimnya. Dengan kata lain sebelum proses-proses emanasi ini teraktualkan, telah ada unsur materi potensial yang apabila ia telah siap maka ia akan teraktualkan menjadi sesuatu. Demikian pendapat beberapa failasuf Muslim mengenai qadim dan baharunya alam. 


\section{DAFTAR PUSTAKA}

Amstrong,Karen Sejarah Tuhan Kisab 4000 Tabun Pencarian Tuban dalam Agama-Agama Manusia, Bandung: Mizan, 2012.

Fakhry, Majid, A History of Islamic Philosophy, Ter. Mulyadhi Kartanegara, Sejarah Filsafat Islam, Jakarta: Pustaka Jaya, 1987.

Hanafi, Ahmad, Pengatar Filsafat Islam, Jakarta: Bulan Bintang, 1990.

Hanafi,Ahmad, Filsafat Skolastik, Jakarta: Pustaka Alhusna, 1983.

Kartanegara, Mulyadhi, Sejarah Filsafat Islam, Jakarta: Pustaka Jaya, 1987.

Madjid, Nurcholish, Khazanah Intelektual Islam, Jakarta: Bulan Bintang, 1994.

Mustofa,H. A. Filsafat Islam, Bandung: Pustaka Setia, 1997

Leaman, Oliver, Everroes and His Philosophy, New York: Clarendon Press Oxford, 1988.

Syarif M. M., Para Filosof Muslim, Bandung: Mizan, 1992. 